\title{
EFECTE DE DIFERENTS FONTS DE SELENI SOBRE LA FUNCIÓ INTESTINAL DE BARRERA

\author{
MORAL-ANTER, DAVID; ${ }^{1}$ CAMPO-SABARIZ, JOAN; \\ FERRER, RUTH; MARTÍN-VENEGAS, RAQUEL
} \\ Departament de Bioquímica i Fisiologia. Secció de Fisiologia. Facultat de Farmàcia i Ciències de l'Alimentació. \\ Universitat de Barcelona
}

\begin{abstract}
In the production of meat chickens it is necessary to complement their diet with selenium in order to ensure optimum growth, reproduction, and health. In the intestine, the main function of selenium is the synthesis of different selenoproteins, such as glutathione peroxidase (GSH-Px) and selenoprotein P1 (SEPP1), which are involved in redox balance. The overall objective of this work was to study the effects of a new organic selenium source compared to an inorganic source in a Caco-2 intestinal cell model. The complementation of cultures with the organic source resulted in an increase in GSH-Px activity, SEPP1 protein expression, and GSH-Px2 genetic expression, as well as a protective effect against hydrogen peroxide. Therefore, it can be concluded that this organic source modifies the activity and expression of different selenoproteins that exert a protector role against oxidative stress, and thus it could be considered a good dietary supplement for the poultry.
\end{abstract}

Keywords: Caco-2, selenoproteins, oxidative stress.

\section{Resumen}

En la producción de pollos de engorde es necesario suplementar su dieta con selenio con el objeto de garantizar un óptimo crecimiento, reproducción y mantenimiento de la salud. En el intestino, la principal función del selenio es la síntesis de diferentes selenoproteínas como la glutatión peroxidasa y la selenoproteína P1, las cuales están implicadas en el balance redox. El objetivo general del trabajo ha sido estudiar los efectos de una nueva fuente orgánica de selenio respecto a una fuente inorgánica en un modelo de células intestinales Caco-2. La suplementación de los cultivos con la fuente orgánica comporta un aumento de la actividad de la GSH-Px, de la expresión proteica de SEPP-1 y de la expresión génica de la GSH-Px2, así como un efecto protector contra el peróxido de hidrógeno. Por lo tanto, los resultados han permitido concluir que esta fuente orgánica modifica la actividad y la expresión de diferentes selenoproteínas que ejercen un papel protector contra el estrés oxidativo, de modo que podría ser considerado un buen suplemento dietético para las aves de corral.

Palabras clave: Caco-2, selenoproteínas, estrés oxidativo

\section{Resum}

En la producció dels pollastres d'engreix és necessari complementar la seva dieta amb seleni per tal de garantir un òptim creixement, reproducció i manteniment de la salut. A l'intestí, la principal funció del seleni és la síntesi de diferents selenoproteïnes, com la glutatió peroxidasa (GSH-Px) i la selenoproteïna P1 (SEPP1), les quals estan implicades en el balanç redox. L'objectiu general del treball ha estat estudiar els efectes d'una nova font orgànica de seleni respecte a una font inorgànica en un model de cèllules intestinals Caco-2. La complementació dels cultius amb la font orgànica comporta un augment de l'activitat la GSH-Px, de l'expressió proteica de SEPP1 i de

${ }^{1}$ Graduat en Farmàcia (ldavidmoral@gmail.com). 
l'expressió gènica de la GSH-Px2, així com un efecte protector davant el peròxid d'hidrogen. Per tant, els resultats han permès concloure que la font orgànica modifica l'activitat i l'expressió de diferents selenoproteïnes que exerceixen un paper protector enfront de l'estrès oxidatiu, de manera que podria ser considerat un bon complement dietètic per a l'aviram.

Paraules clau: Caco-2, selenoproteïnes, estrès oxidatiu.

\section{Introducció}

La dieta de les aus de corral és un factor de gran rellevància pel que fa a l'eficàcia de la seva producció. Els animals han de tenir una dieta equilibrada, en la qual s'aportin les quantitats adequades de cadascun dels nutrients per tal de satisfer les seves necessitats pel que fa als requeriments energètics de creixement, reproducció i salut. Aquests nutrients són proteïnes, carbohidrats, lípids, minerals i vitamines (National Research Council, 1994).

Tot i això, els pinsos utilitzats en la nutrició animal sovint contenen complementacions que no són considerades essencials, però que tenen una gran influència en la salut i el rendiment de l'animal. Alguns exemples d'aquests additius són enzims, antioxidants, probiòtics, prebiòtics, pèptids antimicrobians o àcids orgànics (Ravindran i Son, 2011).

En relació amb els minerals, sovint es classifiquen en dues categories segons la quantitat requerida per tenir una dieta adequada (Edens i Gowdy, 2004):

- Macrominerals: s'expressen com un percentatge sobre el total de nutrients de la dieta.

- Inclouen el calci, el fòsfor, el sodi i el potassi.

- Són essencials per a la correcta integritat estructural de l'organisme i en l'homeòstasi de la regulació osmòtica i del pH.

- Microminerals o elements traça: s'expressen en $\mathrm{mg} / \mathrm{kg}$ de dieta o en $\mathrm{ppm}$.

- IInclouen el manganès, el zinc, el ferro, el coure, el iode i el seleni.

- Formen part de substàncies com hormones, enzims o cofactors específics.

\subsection{Balanç entre substàncies antioxidants i substàncies prooxidants en el tracte gastrointestinal}

Des de fa anys es parla de la hipòtesi sobre el balanç entre substàncies antioxidants i substàncies prooxidants a l'intestí com un important determinant de la salut. Per parlar del terme estrès oxidatiu és important considerar l'oxigen, que és un element essencial per a la vida. Tot i això, també es tracta d'un potent agent capaç de danyar moltes molècules biològiques en forma d'espècies reactives d'oxigen (ROS), les quals poden ser radicals lliures (molècules actives que contenen oxigen) i metabòlits tòxics no radicals d'oxigen. Tanmateix, aquestes ROS es considera que són molècules senyalitzadores involucrades en la regulació de l'expressió gènica, la divisió i diferenciació cel·lular, el creixement i el desenvolupament (Surai et al., 2003).

\subsubsection{Sistemes de defensa contra l'estrès oxidatiu}

Quan es parla de sistemes de defensa antioxidant, es considera que poden actuar en tres nivells diferents (figura 1). 


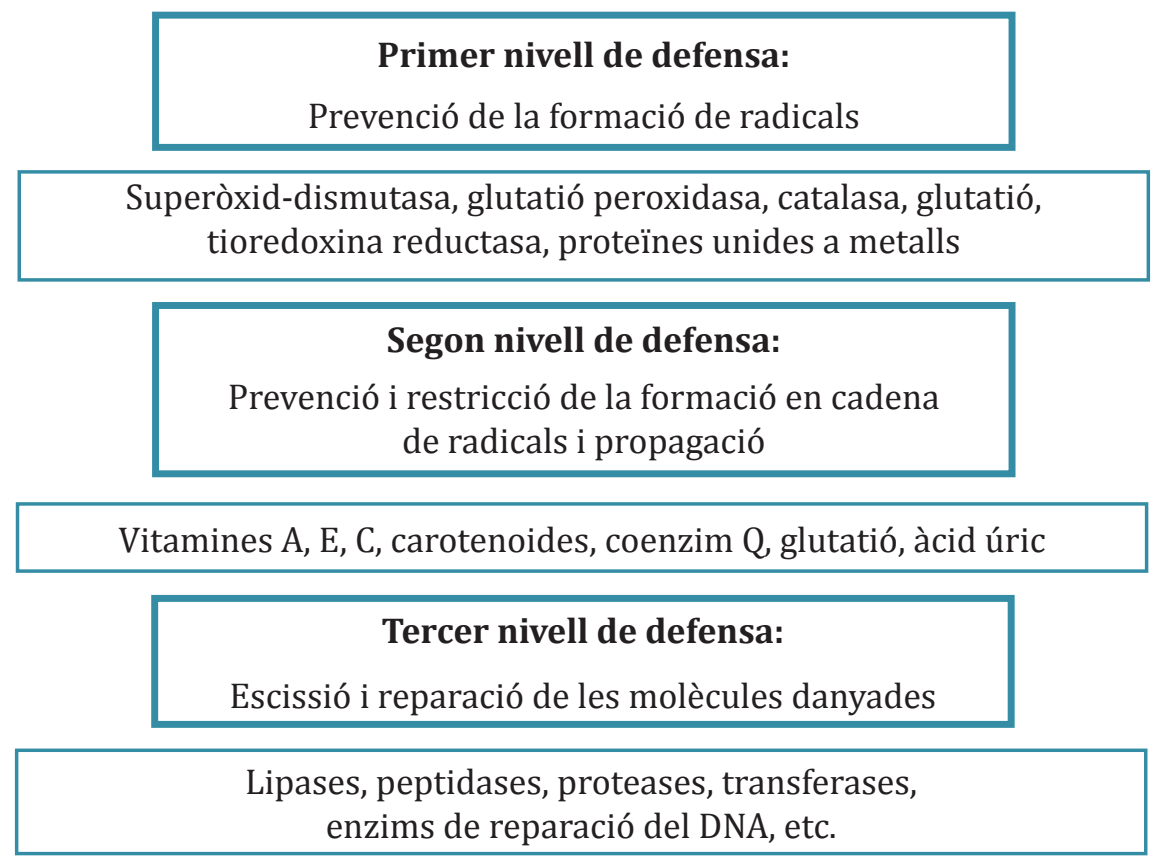

Figura 1. Línies de defensa antioxidant presents en una cèl-lula (imatge adaptada de Surai, 2002).

Dins del primer nivell de defensa (prevenció de la formació de radicals) es troben (Surai, 2002; Surai et al., 2003):

- Enzims de la família superòxid-dismutasa (SOD): són els responsables de la transformació del radical superòxid $\left(\mathrm{O}_{2}^{-}\right)$, que es considera el radical més important que produeixen els sistemes biològics, en peròxid d'hidrogen $\left(\mathrm{H}_{2} \mathrm{O}_{2}\right)$.

- Glutatió-peroxidasa (GSH-Px, enzim dependent de seleni) i catalasa (CAT, enzim dependent de ferro): són enzims responsables de la reducció del $\mathrm{H}_{2} \mathrm{O}_{2}$ a aigua, ja que aquest segueix sent tòxic per a l'organisme, però la GSH-Px té més afinitat pel $\mathrm{H}_{2} \mathrm{O}_{2} \mathrm{i}$ per tant, l'eliminació d'aquest és principalment dependent de l'activitat de la GSH-Px. No obstant això, s'ha descrit que la tioredoxina-reductasa (TrxR) també té la capacitat de reduir el $\mathrm{H}_{2} \mathrm{O}_{2}$.

- Proteïnes unides a metalls (transferrina, lactoferrina, ferritina, mioglobina, etc.): és important eliminar el radical superòxid i el $\mathrm{H}_{2} \mathrm{O}_{2}$, ja que són precursors del radical hidroxil $\left(\mathrm{OH}^{*}\right)$, el qual és encara més perillós i es forma a partir d'un seguit de reaccions amb metalls de transició com el ferro i el coure. Per tant, el fet de mantenir aquests metalls units a proteïnes també es considera una estratègia de defensa.

El primer nivell de defensa normalment no és suficient per a la prevenció de la formació de radicals lliures i la peroxidació de lípids $\mathrm{i}$, per tant, es necessiten compostos antioxidants (vitamina E, ubiquinol, carotenoides, vitamina A, àcid ascòrbic, àcid úric i glutatió) que inhibeixin la peroxidació per mitjà de procurar mantenir la cascada de reaccions tan limitada com sigui possible (Surai et al., 2003).

Quan el segon nivell de defensa tampoc no evita la peroxidació lipídica i el dany de molècules biològiques (proteïnes i ADN), entra en joc el tercer nivell, basat en sistemes de reparació d'aquestes 
per tal de mantenir la integritat del genoma, com ara lipases, peptidases o proteases, enzims de reparació de l'ADN, lligases, nucleases, polimerases, fosfolipases i transferases (Surai et al., 2003). A més, s'ha vist que la selenometionina (Se-Met) és un component que pot induir la resposta de reparació de I'ADN (Seo et al., 2002).

\subsubsection{Substàncies prooxidants}

Pel que fa als agents prooxidants, en la dieta hi ha present un ampli ventall de substàncies que no es poden evitar, com àcids grassos poliinsaturats oxidats, esterols oxidats, ions de ferro i coure, nitrits, nitrats, traces de micotoxines, metalls pesants com el mercuri o el plom, així com contaminants orgànics persistents en el medi, entre d'altres. Sovint no cal que es trobin a altes concentracions per tal que tinguin efectes nocius, ja que quan es troben combinats a baixes concentracions també tenen la capacitat d'actuar i són una font important de producció de radicals lliures en el tracte gastrointestinal quan activen el sistema immunitari (Surai et al., 2003).

\subsubsection{Substàncies antioxidants}

Aquests components són els que en situacions d'estrès oxidatiu, quan els agents prooxidants han activat el sistema immunitari produint radicals lliures, poden tenir un efecte protector sobre l'organisme. Les substàncies antioxidants també poden provenir de la dieta, com, per exemple, la vitamina $\mathrm{E}$, el coenzim Q, els carotenoides, la vitamina A, l'àcid ascòrbic o vitamina C, el glutatió reduït, els flavonoides, altres polifenols i el seleni. A més, es creu que els components antioxidants sintetitzats dins del mateix organisme, com alguns enzims o el glutatió, entre d'altres, podrien tenir la capacitat de millorar la protecció contra els radicals lliures en l'intestí (Surai et al., 2003).

Pel que fa al seleni provinent de la dieta, actua com una font per a la síntesi de selenoproteïnes, tot i que hi ha evidències que consideren que per ell mateix actua com un antioxidant (Surai et al., 2004).

\subsection{Complementació de les dietes per a aviram amb seleni}

El seleni va començar a ser emprat en el camp de la medicina des de l'any 1911, ja que es va veure que si s'administrava per via intravenosa a ratolins malalts de carcinoma d'Ehrlich i sarcoma, era capaç d'eliminar el tumor gràcies a la seva propietat necrosant. A principis de la Segona Guerra Mundial, el 1943, va deixar d'utilitzar-se terapèuticament perquè es va veure que l'element en si era carcinogen (Schrauzer i Surai, 2009). Tanmateix, l'any 1957 Schwarz i Foltz van demostrar que el seleni és un element essencial en la nutrició del dia a dia, a causa del seu efecte antioxidant, i, per tant, en la salut animal i humana (Edens i Gowdy, 2004; Brandt-Kjelsen et al., 2017).

Molts aliments contenen seleni provinent del sòl, però aquesta aportació normalment és molt baixa i, per tant, insuficient per cobrir les necessitats de l'animal. És per aquesta raó que l'any 1974 la Food and Drug Administration (FDA) va aprovar el seleni en forma de selenit o selenat de sodi com a complement en les dietes d'animals de granja amb l'objectiu d'assolir un rendiment òptim dels animals que estan destinats al consum humà (Brandt-Kjelsen et al., 2017).

Algunes de les funcions més rellevants del seleni estan relacionades amb la formació de selenoproteïnes involucrades en el manteniment del balanç oxidació-reducció de l'organisme davant de situacions d'estrès oxidatiu (Edens i Gowdy, 2004; Surai, 2006), desenvolupament dels sistemes d'alta renovació, com són el sistema immunitari o el digestiu, així com en l'envelliment i el càncer (Surai, 2002). Tot i això, hi ha una gran controvèrsia pel que fa al seleni, ja que és considerat un element essencial però amb un marge de seguretat i d'eficàcia molt estret. Així doncs, per una banda, un dèficit d'aquest element en l'aportació a la dieta es relaciona amb un menor rendiment productiu dels ani- 
mals de granja i un augment de la susceptibilitat de patir diferents malalties. Per altra banda, a dosis massa elevades produeix toxicitat i el seu ús pot donar lloc a problemàtiques en l'àmbit de la contaminació ambiental (Lyons et al., 2007). Per tant, les recomanacions sobre la complementació amb seleni de la dieta dels animals de granja estan dissenyades de cara a cobrir els requeriments de l'element sense comprometre la seguretat del consumidor (Brandt-Kjelsen et al., 2017), tot i que la forma química que s'ha d'afegir als pinsos no està especificada (Schrauzer i Surai, 2009).

\subsubsection{Fonts de seleni}

En la complementació de les dietes d'aviram, les fonts de seleni emprades es classifiquen principalment en dues formes químiques: inorgàniques i orgàniques. Per una banda, la principal font inorgànica de seleni és el selenit, encara que també són conegudes altres formes com el selenat o l'àcid selenhídric (Surai, 2002)being an integral part of selenoproteins participating in the regulation of various physiological processes in the body. As a part of glutathione peroxidase (GSH-Px. D'altra banda, les fonts orgàniques naturals de l'element són els anàlegs del seleni dels aminoàcids metionina (Se-Met) i cisteïna (Se-Cys), presents principalment en llavors, cereals i llevats (Khan et al., 2016).

\subsubsection{Fonts inorgàniques}

Les fonts inorgàniques de seleni són molt econòmiques i han permès reduir la incidència de malalties associades a la deficiència de seleni. Tot $i$ això, han estat objecte de força controvèrsia pels inconvenients associats al seu ús, com ara la toxicitat, les interaccions amb altres minerals i vitamines, i la seva incapacitat per crear i mantenir reserves de seleni dins l'organisme, a causa de la seva mala retenció i baixa eficiència per transferir-se en els teixits (Khan et al., 2016).

\subsubsection{Fonts orgàniques}

El Se-Met és la principal font orgànica natural de seleni que reben els animals, juntament amb el SeCys, atès que junts constitueixen un $50-80 \%$ del seleni total ingerit (Surai, 2002)being an integral part of selenoproteins participating in the regulation of various physiological processes in the body. As a part of glutathione peroxidase (GSH-Px. Els animals obtenen aquesta forma de seleni a partir de les plantes locals i dels cultius que la contenen, essencialment unida a proteïnes (Schrauzer, 2000; Schrauzer, 2003). Aquest anàleg de la metionina s'incorpora a algunes proteïnes i així es formen en òrgans i teixits reserves de seleni que en moments de necessitat pot tornar de manera reversible a la circulació sanguínia. Aquesta és una propietat única que no comparteix amb cap altre selenoaminoàcid i, a més, fa que compleixi amb els criteris necessaris per considerar-lo un aminoàcid essencial, atès que totes les formes metabòliques necessàries de seleni es poden produir a partir de la Se-Met (Schrauzer, 2000; Schrauzer, 2003; Edens i Gowdy, 2004). L’any 2000 l'ús de Se-Met va ser aprovat per l'FDA com a complement alimentari en les dietes per a aviram.

En la recerca de noves fonts de seleni es va desenvolupar un cultiu de llevats amb un contingut elevat de seleni orgànic (aproximadament $1.000 \mu \mathrm{g}$ en forma de Se-Met lligata proteïnes), els primers lots dels quals van sortir durant els anys setanta (Schrauzer, 2003; Rayman et al., 2008). Aquesta manera de complementar la dieta de pollastres amb seleni va representar un avantatge respecte a la resta, ja que eliminava la necessitat d'elaborar premescles de seleni i era relativament estable durant l'emmagatzemament, a diferència de les sals inorgàniques de seleni i la Se-Met semisintètica (Surai, 2006). Fins l'any 2003 l'FDA no va aprovar el seu ús com a complement en dietes per a totes les espècies animals, sota el nom comercial Sel-Plex (Schrauzer i Surai, 2009). 
Segons la informació recollida en els darrers anys, la substitució de selenit per fonts orgàniques de seleni en dietes per a aviram ha millorat la fertilitat i viabilitat dels pollastres pel que fa al seu desenvolupament primerenc, a més que es transfereixen millor als ous i, per tant, a l'embrió, de manera que ajuden el pollastre a superar l'estrès oxidatiu que li comporta sortir de l'ou (Surai, 2006).

\subsubsection{Selenoproteïnes}

El seleni, un cop en la circulació sistèmica i a través de les selenoproteïnes, té la capacitat de dur a terme diferents funcions fisiològiques i bioquímiques, les quals són necessàries per al manteniment de l'homeòstasi de l'organisme (Edens i Gowdy, 2004). A l'intestí, les selenoproteïnes més importants són la GSH-Px, la TrxR i la selenoproteïna P (SEPP1) (Surai et al., 2004).

La GSH-Px és una selenoproteïna que forma part de la família dels enzims antioxidants que utilitzen el glutatió per reduir de manera eficient les ROS, atès que té un paper fonamental en la reducció d'agents oxidants en la mucosa intestinal (Speckmann i Steinbrenner, 2014). Aquest enzim està dotat d'una activitat que forma part d'un dels sistemes de resposta davant d'una situació d'estrès oxidatiu (National Research Council, 1994). És més, l'any 1973 es va detectar que el seleni era un component essencial per a aquest enzim (Surai, 2002), de manera que la seva contribució a través de la dieta és un element de gran importància per tal de regular l'activitat d'aquest enzim i, com a conseqüència, l'eficàcia dels sistemes antioxidants (Surai, 2016). Hi ha quatre isoformes que s'han trobat a l'intestí, però la GSH-Px1 i la GSH-Px2 són les que tenen una importància especial. Es troben a l'epiteli intestinal i tenen una especificitat molt similar per al seu substrat. Segons s'ha descobert, la GSH-Px1 es distribueix al llarg de tot l'eix cripta-vellositat, mentre que la GSH-Px2 predomina fonamentalment en les criptes. Una altra isoforma present a l'intestí és la GSH-Px3, la qual és secretada pels enteròcits cap a la llum intestinal i participa en el manteniment de la mucosa intestinal enfront del dany oxidatiu. Finalment, la GSH-Px4 es localitza a l'intestí prim i el còlon, i la seva expressió no es veu afectada per la deficiència d'aportació de seleni a la dieta (Circu i Aw, 2011).

La TrxR és un enzim que pertany a la superfamília de les oxidoreductases i també està dotada de propietats antioxidants, així com la GSH-Px (Surai, 2002). Aquesta selenoproteïna participa en processos de resposta immunitària dins la mucosa intestinal, on la seva expressió es veu molt incrementada (Circu \& Aw, 2011). Segons la complementació de seleni que s'aporti per la dieta, s'ha comprovat que es pot modificar la seva activitat (Surai 2002).

Pel que fa a la SEPP1, com en el cas de les dues selenoproteïnes descrites anteriorment, també s'han trobat evidències que té un seguit de propietats antioxidants (Speckmann et al., 2014), tot i que la seva funció principal és transportar seleni als teixits. A més, malauradament s'ha comprovat que quan la concentració de SEPP1 és baixa, la incidència en el desenvolupament de la malaltia intestinal inflamatòria i del càncer colorectal es veu incrementada. Tot i això, es pensa que la depleció de l'absorció del seleni podria ser un factor íntimament relacionat amb el mecanisme que produeix aquesta reducció durant el desenvolupament d'aquestes malalties (Kudva et al., 2015).

\section{Objectius}

La producció moderna d'aus de corral centra els esforços a optimitzar al màxim el seu rendiment, la qual cosa comporta que aquests animals tinguin una sensibilitat elevada a les situacions d'estrès, ja que han de suportar una alta taxa de creixement en un temps de vida relativament curt. Tanmateix, cal considerar que el tracte gastrointestinal està exposat a ROS que deriven del propi metabolisme de l'enteròcit, dels aliments ingerits i de les cèlllules immunitàries residents, entre altres factors (De Spirt et al., 2016). Així doncs, una òptima funció intestinal de barrera és essencial per mantenir un bon estat de salut i representa una línia clau de defensa contra l'estrès oxidatiu. Com ja s'ha descrit, 
la suplementació amb seleni té un paper clau en la regulació de l'estat oxidatiu de la cèlllula. La complementació de la dieta de pollastres d'engreix amb seleni és un procediment rutinari. Tradicionalment, el seleni s'ha afegit en forma de sals inorgàniques. No obstant això, les formes orgàniques de seleni són menys tòxiques i més biodisponibles, fet que comporta que actualment estiguin més subjectes a estudi per tal d'utilitzar-les com a fonts de seleni.

Així, l'objectiu general del projecte que emmarca aquest treball és avaluar l'efecte d'una nova font orgànica de seleni sobre la salut intestinal, tot comparant l'efecte amb una font inorgànica. La procedència de les fonts de seleni utilitzades en aquest estudi no es pot detallar per raons de confidencialitat.

Els objectius específics que s'han dut a terme en aquest treball amb cultius de cèlllules Caco-2 són els següents:

- Establir un model cellular deficient en seleni. Per assolir aquest objectiu s'ha determinat l'activitat de la GSH-Px i l'expressió gènica de la GSH-Px2, així com l'expressió proteica i gènica de la SEPP1 en presència i en absència de seleni.

- Estudiar l'efecte de la complementació amb les diferents fonts de seleni sobre les selenoproteïnes esmentades en el punt anterior.

- Avaluar el possible efecte protector de les diferents fonts de seleni en cultius incubats amb $\mathrm{H}_{2} \mathrm{O}_{2}$. Per assolir aquest objectiu s'ha determinat la producció de ROS, la peroxidació lipídica i l'oxidació proteica en presència de les diferents fonts de seleni.

\section{Material i mètodes}

\subsection{Material}

El medi de cultiu Dulbecco's Modified Eagle's Medium (DMEM), la tripsina, el TRI-Reagent, la penicillina i l'estreptomicina han estat proveïdes per Life Technologies (Carlsbad, CA, EUA). Els aminoàcids no essencials, la solució amortidora de fosfats estèrils (Dulbecco's Phosphate Buffered Saline (PBS), pH 7,3), el taronja d'acridina i el bromur d'etidi procedeixen de Sigma (Saint Louis, MO, EUA). El sèrum fetal boví (SFB) s'ha adquirit a GE Healthcare Life Sciences (Issaquah, WA, EUA). El material estèril per al manteniment dels cultius celllulars prové de Costar (Cambridge, MA, EUA).

\subsection{Manteniment dels cultius cel-lulars}

Les cèllules Caco-2 provenen de l'European Collection of Cell Cultures (Salisbury, Regne Unit). Aquesta línia cel-lular s'ha mantingut a $37^{\circ} \mathrm{C}$ en una atmosfera modificada de $5 \% \mathrm{de}_{2}$, tal com s'ha descrit anteriorment (Martín-Venegas et al., 2006)water, and solutes. Morphological changes during cell differentiation, as well as changes in the activity of brush-border enzymes and the expression of transport proteins, are well established. However, little is known about the arachidonic acid (AA. Les cèlllules s'han fet créixer de manera rutinària en flascons de plàstic a una densitat de 10.000 cèlllules/ $\mathrm{cm}^{2}$ en DMEM, el qual conté 4,5 g/L de D-glucosa i $2 \mathrm{mmol} / \mathrm{L}$ de L-glutamina per si mateix i s'ha complementat amb un $1 \%(\mathrm{v} / \mathrm{v})$ d'aminoàcids no essencials, un $10 \%(\mathrm{v} / \mathrm{v})$ de SFB inactivat per temperatura a $56{ }^{\circ} \mathrm{C}, 100 \mathrm{UI} / \mathrm{mL}$ de penicillina i $100 \mu \mathrm{L} / \mathrm{mL}$ d'estreptomicina. Passats vuit dies, el cultiu assoleix aproximadament el $80 \%$ de la seva confluència, se'n treu el medi el medi i es posa tripsina en el cultiu per tal que les cèllulues es desenganxin de la base del flascó i puguin sembrar-se de nou en flascons o en plaques de 24 pous. 
El recompte de les cèlllules viables a l'hora de realitzar la sembra en els diferents suports s'ha dut a terme per observació en un microscopi de fluorescència (Zeiss MC80, Alemanya) i amb la tinció prèvia amb taronja d'acridina i bromur d'etidi en condicions absents de llum (Martín-Venegas et al., 2006).

\subsection{Disseny experimental}

\subsubsection{Determinació de les activitats lactat-deshidrogenasa (LDH) i GSH-Px, expressió proteica de SEPP1 i expressió gènica de la GSH-Px i SEPP1}

Un cop se sembren les cèlllules en els flascons, es mantenen durant 2 setmanes amb DMEM complementat amb SFB, o es treu aquest SFB durant la segona setmana per tenir un model de cèlllules amb depleció de seleni. Durant aquest temps, els cultius formen una monocapa de cèlllules diferenciades amb característiques morfològiques, bioquímiques i funcionals similars a les dels enteròcits de l'intestí prim (Martín-Venegas et al., 2006). Transcorregudes aquestes 2 setmanes, s'afegeixen en el medi les diferents fonts de seleni a determinades concentracions i es deixen incubar durant $72 \mathrm{~h}$.

Per una banda, es recullen $100 \mu \mathrm{L}$ del medi en un Eppendorf $\circledast$, amb compte de no agafar cèl-lules, i s'emmagatzemen a $-80^{\circ} \mathrm{C}$. Posteriorment es duu a terme la determinació de l'activitat de la LDH. D'altra banda, es procedeix al rentat dels flascons per triplicat amb PBS a $4{ }^{\circ} \mathrm{C}$, ja que les restes de DMEM podrien interferir amb els passos següents, es desenganxen les cèlllules de la base del flascó amb l'ajuda d'una rasqueta, es recullen en un Eppendorf® amb $600 \mu \mathrm{L}$ de PBS i s'emmagatzemen a $-80^{\circ} \mathrm{C}$. Amb l'objectiu d'obtenir el contingut de les cèlllules, aquestes se sotmeten a una sonda d'ultrasons ( 40 pulsacions a $4{ }^{\circ} \mathrm{C}$, Soniprobe, Dawe Instruments Limited, Brentford, Middlesex, Regne Unit) per tal de lisar-les. Per acabar, se centrifuga (Accuspin Micro 17R, Fisher Scientific, Hampton, NH, EUA) la suspensió obtinguda a 10.000 rpm durant 15 minuts a $4{ }^{\circ} \mathrm{C}$ i se separa el sobrenedant per tal de determinar l'activitat GSH-Px, la concentració total de proteïnes i l'expressió proteica de SEPP1. El sediment (pellet) restant s'utilitza per determinar l'expressió gènica de la GSH-Px i SEPP1 (figura 2).

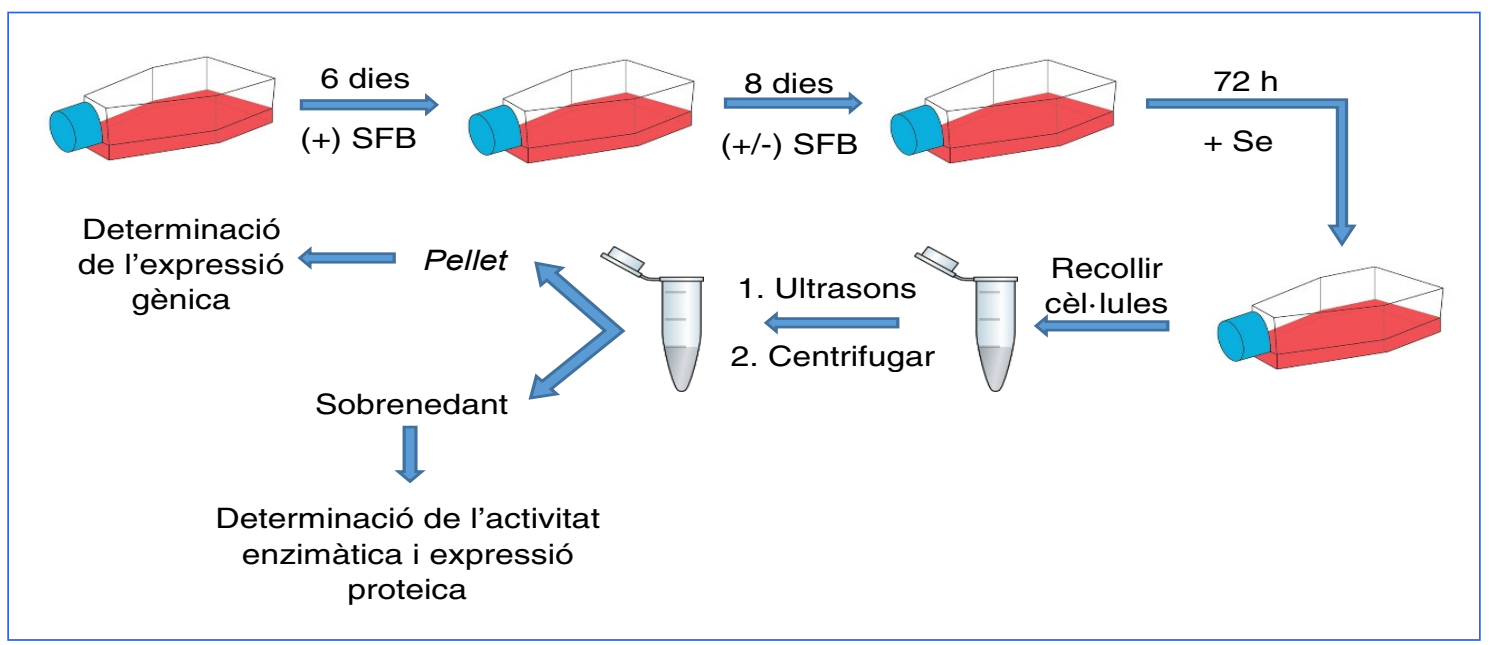

Figura 2. Disseny experimental per a la determinació d'activitats enzimàtiques i l'expressió proteica i gènica en un model de cèlllules Caco-2 en depleció o no de seleni. 


\subsubsection{Determinació de ROS intracel-lulars, de l'oxidació proteica i de la peroxidació lipídica}

Un cop sembrades les cèlllules en plaques de 24 pous, s'hi mantenen durant 2 setmanes per tal que es formi una monocapa de cèlllules diferenciades. D'aquestes 2 setmanes, a principis de la segona es treu l'SFB per tenir un model de cèlllules amb depleció de seleni. Un cop passat aquest interval, s'afegeixen les diferents fonts de seleni a determinades concentracions i s'incuben durant $24 \mathrm{~h}$. Al dia següent s'afegeix $1 \mathrm{mM}$ de $\mathrm{H}_{2} \mathrm{O}_{2}$ al cultiu i s'incuba durant $3 \mathrm{~h}$. Transcorregut aquest temps, hi ha dues vies possibles depenent de l'objectiu de l'experiment.

Per una banda, es pot procedir directament a la determinació de les ROS (figura 3). De l'altra, es pot realitzar el rentat dels pous amb PBS a $4{ }^{\circ} \mathrm{C}$, ja que les restes de DMEM podrien interferir amb els passos següents, es desenganxen les cèlllules de la base del pou amb l'ajuda d'una rasqueta, es recullen en un Eppendorf ${ }^{\circ}$ amb $100 \mu \mathrm{L}$ de PBS i s'emmagatzemen a $-80{ }^{\circ} \mathrm{C}$. Per tal de determinar l'oxidació proteica i la peroxidació lipídica, les mostres es processen com ja s'ha explicat en l'apartat anterior (figura 3).

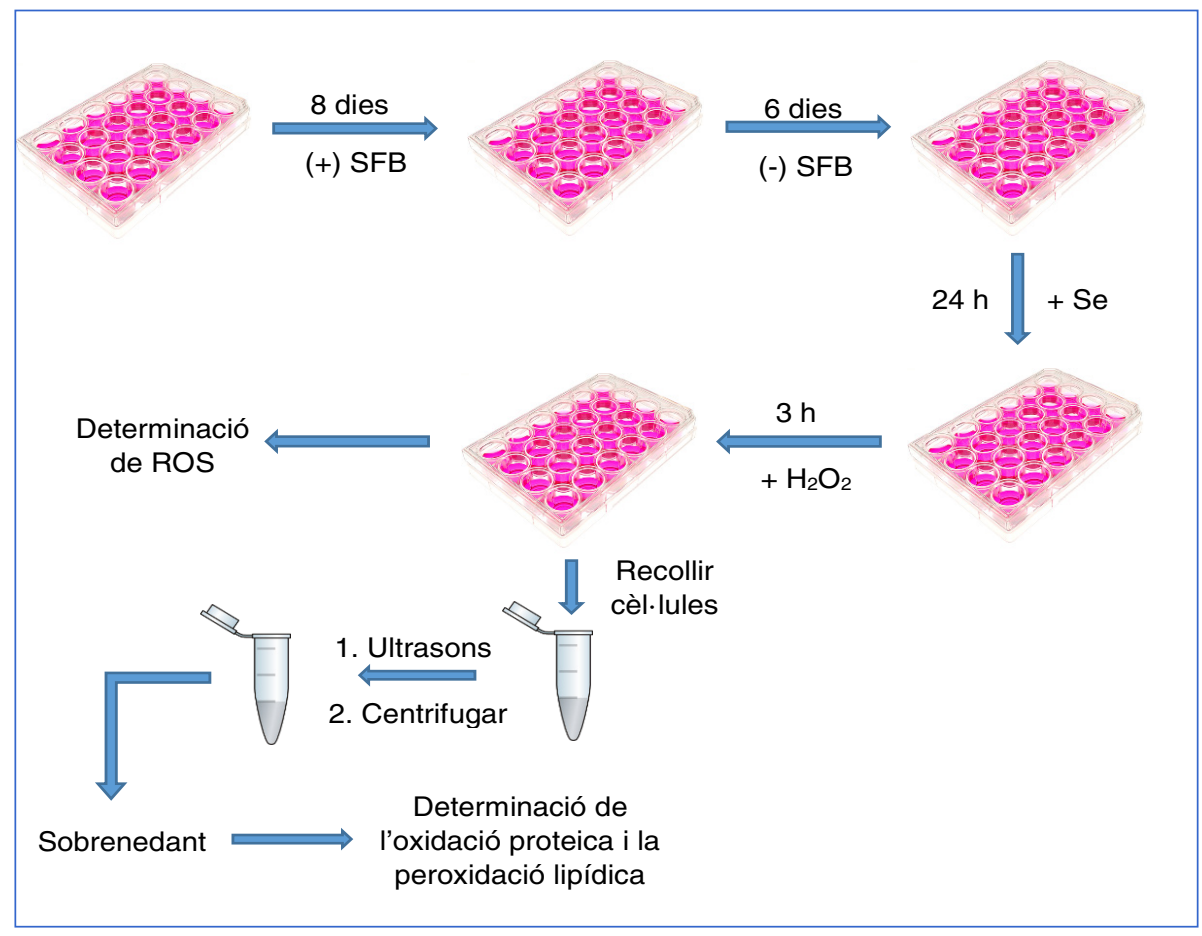

Figura 3. Disseny experimental per a la determinació de ROS, de l'oxidació proteica i de la peroxidació lipídica en un model de cèlllules Caco-2 en depleció de seleni.

\subsection{Determinació de l'activitat GSH-Px}

L'activitat d'aquest enzim s'ha determinat emprant el kit comercial Glutathione Peroxidase Assay Kit (Cayman Chemical, Ann Arbor, MI, EUA) seguint el protocol del fabricant. Aquest kit mesura l'activitat de la GSH-Px de manera indirecta per mitjà d'una reacció acoblada a l'enzim glutatió-reductasa. Els resultats s'expressen en $\mathrm{nmol} / \mathrm{min}$ i es normalitzen per $\mathrm{mg}$ de proteïna total que conté la mostra. 


\subsection{Determinació de l'expressió proteica de la SEPP1}

L'expressió proteica de la SEPP1 s'ha determinat per mitjà d'un kit d'enzimoimmunoassaig sobre fase sòlida (ELISA) de tipus sandvitx (Human Selenoprotein P ELISA Kit, Cusabio, província de Hubei, Xina), és a dir, una tècnica d'immunoassaig en la qual en una placa de 96 pous es recobreix cadascun dels pous amb un primer anticòs anti-SEPP1. Tot seguit es renta l'excés d'anticòs i s'introdueix en cada pou un volum de sobrenedant on es troba la proteïna, la qual es reté al fons del pou ja que és reconeguda per l'anticòs. Es torna a rentar la placa per tal d'eliminar les restes no retingudes i es torna a afegir una solució on hi ha present un segon anticòs anti-SEPP1 marcat amb un enzim, de manera que la proteïna es troba unida a tots dos anticossos. S'afegeix el substrat de l'enzim i es deixa incubar durant un temps establert en el qual es produeix la reacció enzimàtica. Un cop ha passat el temps d'incubació, es frena la reacció amb una solució stop. Per acabar, l'absorbància es mesura per espectrofotometria a una longitud d'ona d'emissió de $450 \mathrm{~nm}$ (TECAN, Sunrise, Grödig, Àustria). Els resultats s'expressen en ng i es normalitzen per mg de proteïna total que conté la mostra.

\subsection{Determinació de la concentració de proteïnes}

La concentració de proteïnes presents a les mostres s'ha determinat seguint el mètode descrit per Bradfort (Bradford, 1976). Les mostres i els patrons preparats prèviament a partir d'albúmina sèrica bovina s'agiten i es procedeix a la lectura amb l'espectrofotòmetre a $595 \mathrm{~nm}$ (Shimadzu UV-160 A, Kyoto, Japó).

\subsection{Determinació de l'expressió gènica de la GSH-Px2 i de la SEPP1}

L'expressió dels gens es determina per reacció en cadena per la polimerasa-transcriptasa inversa (RTPCR) (Life Technologies, Carlsbad, CA, EUA), la qual necessita un seguit de passos previs abans de poder realitzar-se. En primer lloc, es parteix d'una extracció de l'ARN total provinent del sediment de cèllules emprant el reactiu TRI-Reagent. Posteriorment, la concentració d'ARN es determina per mitjà de l'aparell NanoDrop ND-1000 (NanoDrop Technologies, Inc., Wilmington, EUA). De l'ARN total quantificat, es duu a terme la transcripció inversa d'1 $\mu$ g d'ARN utilitzant el kit High Capacity RNA-to-cDNA (Life Technologies, Carlsbad, CA, EUA) en un termociclador (Thermomixer Comfort, Eppendorf, Hamburg, Alemanya) a una temperatura de $37^{\circ} \mathrm{C}$ durant 60 minuts, tal com indiquen les recomanacions del fabricant. La reacció s'inactiva incrementant la temperatura a $95^{\circ} \mathrm{C}$ durant 5 minuts.

L'ADNc obtingut se sotmet a una anàlisi per RT-PCR (ABI Prism 7900 Real-Time PCR System, Life Technologies) emprant una sonda específica per als gens d'interès dissenyada i validada prèviament (TaqMan Gene Expression Assays, Life Technologies), d'acord amb les recomanacions del fabricant. Aquesta anàlisi es fa en els Centres Científics i Tecnològics de la Universitat de Barcelona. El gen de referència utilitzat ha estat el Ribosomal Protein Lateral stalk subunit P0 (RPLP0, Life Technologies) per tal de normalitzar els resultats d'expressió gènica obtinguts. Finalment, aquesta expressió relativa s'ha executat per mitjà de l'eina informàtica 7500 Systems SDS Software Version 2.4 (Life Technologies, Carlsbad, CA, EUA).

\subsection{Determinació de ROS intracel-lulars}

La generació de ROS per part de les cèlllules Caco-2 s'ha determinat emprant el kit comercial Oxiselect Intracellular ROS Assay Kit (Cell Biolabs Inc., San Diego, CA, EUA). Aquest assaig necessita el diacetat-2',7'-diclorohidrofluoresceïna (DCFH-DA) com a sonda fluorogènica capaç de difondre a través de les cèlllules. 
Un cop transcorregudes $24 \mathrm{~h}$ després d'afegir les diferents fonts de seleni al cultiu, es renta, s'hi afegeix DCFH-DA (100 mM) i s'incuba a $37^{\circ} \mathrm{C}$ durant 45 minuts en condicions absents de llum per tal que penetri a l'interior de les cèl-lules, on les esterases actuen transformant el compost en 2',7'-diclorohidrofluoresceïna (DCFH), el qual s'oxida ràpidament en contacte amb ROS i esdevé 2',7'-diclorodihidrofluoresceïna (DCF), que és la molècula final que emet fluorescència. La intensitat de la fluorescència, per tant, és proporcional a la producció de ROS dins el citoplasma de les cèlllules. La lectura de la intensitat de la fluorescència es realitza en dos temps, a temps $0 \mathrm{~h}$ i després de $3 \mathrm{~h}$, a una longitud d'ona d'excitació de $480 \mathrm{~nm}$ i d'emissió de $535 \mathrm{~nm}$ (Wallac 1420 Victor3, Perkin-Elmer, Waltham, MA, EUA). Els resultats s'expressen com a percentatge de variació de la fluorescència produït durant l'experiment.

\subsection{Determinació de la peroxidació lipídica i de l’oxidació proteica}

Per una banda, els peròxids lipídics són uns indicadors molt inestables de l'estrès oxidatiu en les cèllules i es transformen en productes més reactius i complexos, com el 4-hidroxinonenal (4-HNE). D'altra banda, l'oxidació proteica es produeix per la reacció d'una proteïna directament amb ROS o indirectament amb productes secundaris de l'estrès oxidatiu. Els productes de l'oxidació proteica més comuns en les mostres biològiques són les proteïnes que contenen derivats carbonils en els residus de prolina, arginina, lisina i treonina.

Per a la determinació de la peroxidació lipídica i l'oxidació proteica s'han emprat dos kits d'ELISA (OxilSelect HNE Adduct Competitive ELISA Kit, Cell Biolabs Inc., i OxiSelect Protein Carbonyl ELISA Kit, Cell Biolabs Inc., respectivament) seguint les instruccions del fabricant. L'absorbància dels adductes proteics amb hidroxinonenal (HNE) i dels grups carbonil s'ha determinat a una longitud d'ona de 450 $\mathrm{nm}$ (TECAN) per a totes dues determinacions. Els resultats s'expressen en pmol per a la peroxidació lipídica i en nmol per a l'oxidació proteica. Aquests resultats es normalitzen per mg de proteïna total que conté la mostra.

\subsection{Determinació de l'activitat de la LDH. Assaig de viabilitat cellular}

Amb la finalitat de calcular la viabilitat cel-lular, aquest assaig es basa a mesurar l'activitat de la LDH, un enzim citoplasmàtic que s'allibera al medi de cultiu en condicions en les quals la membrana cellular es troba danyada. Aquest assaig s'ha dut a terme amb el kit BioChain's LDH Cytotoxicity Assay, que és un assaig colorimètric, i s'ha fet seguint les instruccions del fabricant. Finalment, es mesura l'absorbància del formazan que s'ha format a $490 \mathrm{~nm}$ (TECAN). Els resultats s'expressen com a densitat òptica.

\subsection{Anàlisi estadística}

Un cop realitzats els experiments i obtinguts els resultats, aquests s'expressen com una mitjana \pm l'error estàndard (ES). Totes les dades s'han comparat utilitzant l'anàlisi de la variància (ANOVA), seguida de la prova post hoc de Bonferroni que disposa el paquet estadístic IBM SPSS Statistics 22 (SPSS Inc. Chicago, IL, EUA). En tots els casos, un valor de $\mathrm{P}<0,05$ s'ha considerat que denota diferències estadísticament significatives. 


\section{Resultats i discussió}

\subsection{Establiment del model de deficiència de seleni}

El primer objectiu del treball ha estat la posada a punt d'un model cel-lular que fos deficient en seleni. Aquests resultats han estat presentats al III Workshop Anual de l'INSA-UB (Campo-Sabariz et al., 2017). Aquest model s'ha establert tenint en compte que la font de seleni dels cultius prové del SFB. En aquest sentit, el grup de recerca va determinar que la concentració de seleni present en l'SFB emprat en aquest estudi és de 153,1 $\pm 3,6 \mathrm{nM}$ i, un cop addicionat en el medi de cultiu, la concentració final és de 13,9 $\pm 0,3 \mathrm{nM}$.

Les variables que s'han considerat per posar a punt el model han estat l'activitat de la GSH-Px i l'expressió gènica de la GSH-Px2, així com l'expressió proteica i gènica de la SEPP1, ja que són selenoproteïnes amb una funció cabdal a la zona intestinal. Aquestes variables s'han determinat en cultius de cèl-lules Caco-2 mantingudes en presència o en absència de SFB i els resultats es mostren en la figura 4.

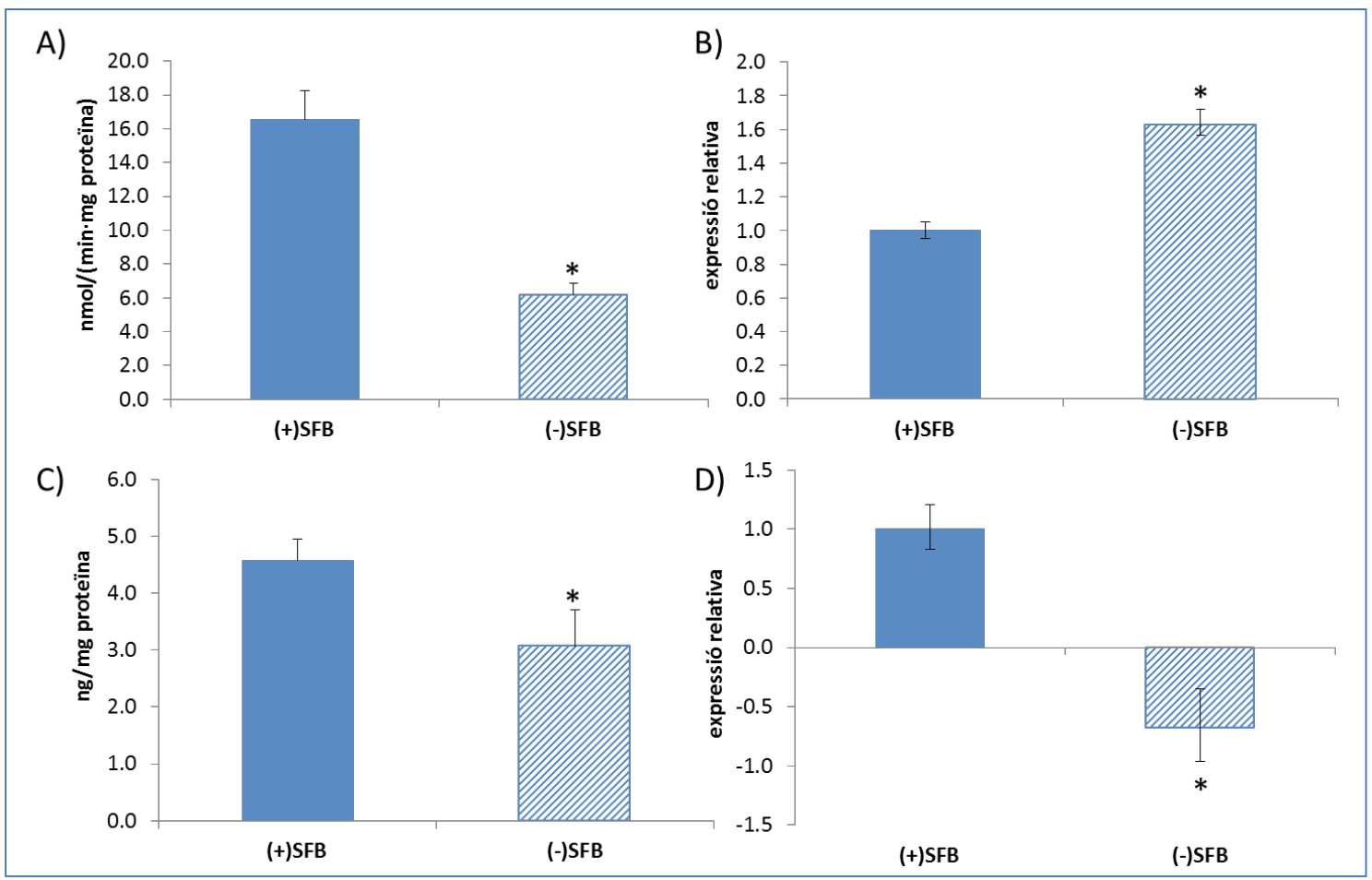

Figura 4. Activitat GSH-Px (A), expressió gènica de laGSH-Px2 (B), expressió proteica (C) i expressió gènica (D) de la SEPP1 en cèl-lules Caco-2 mantingudes en presència o en absència de SFB. Els resultats s'expressen com a mitjana \pm SE de $n=4-9$ cultius. L'asterisc denota diferències estadísticament significatives $(\mathrm{P}<0,05)$.

Els resultats mostren que, en absència de $S F B$, es produeix una disminució de l'activitat de la GSH-Px, mentre que l'expressió gènica de la GSH-Px2 es veu incrementada (figura 4, A i B). Aquests resultats concorden amb els d'un estudi anterior fet en el mateix model cel-lular (Zeng et al., 2008). De fet, es considera aquesta activitat com un bon marcador de la biodisponibilitat de seleni. La bibliografia reporta que una disminució d'aquesta activitat va acompanyada d'una disminució de l'expressió gènica de la majoria de les isoformes presents a l'intestí, com és el cas de la GSH-Px1 (Maciel-Dominguez et al., 2013; De Spirt et al., 2016). En canvi, en el cas de la GSH-Px2, 
tot i que una absència de seleni provoca una reducció de l'expressió d'aquesta selenoproteïna (De Spirt et al., 2016), la seva expressió gènica augmenta (Maciel-Dominguez et al., 2013), probablement en resposta a l'estrès oxidatiu que pateix la cèllulu en absència de SFB. En el nostre cas, hem demostrat que la producció de ROS en cèlllules Caco-2 mantingudes en absència de SFB és més elevada que la de les que s'han mantingut en presència de SFB (figura 5). A més a més, s'ha descrit que una deficiència de seleni i, per tant, de la síntesi de selenoproteïnes, comporta una inducció del factor de transcripció Nrf2, que regula l'expressió de nombrosos gens d'enzims antioxidants. Contràriament però, una activació de Nrf2 indueix la transcripció de la GSH-Px2 i TrxR1 (De Spirt et al., 2016).

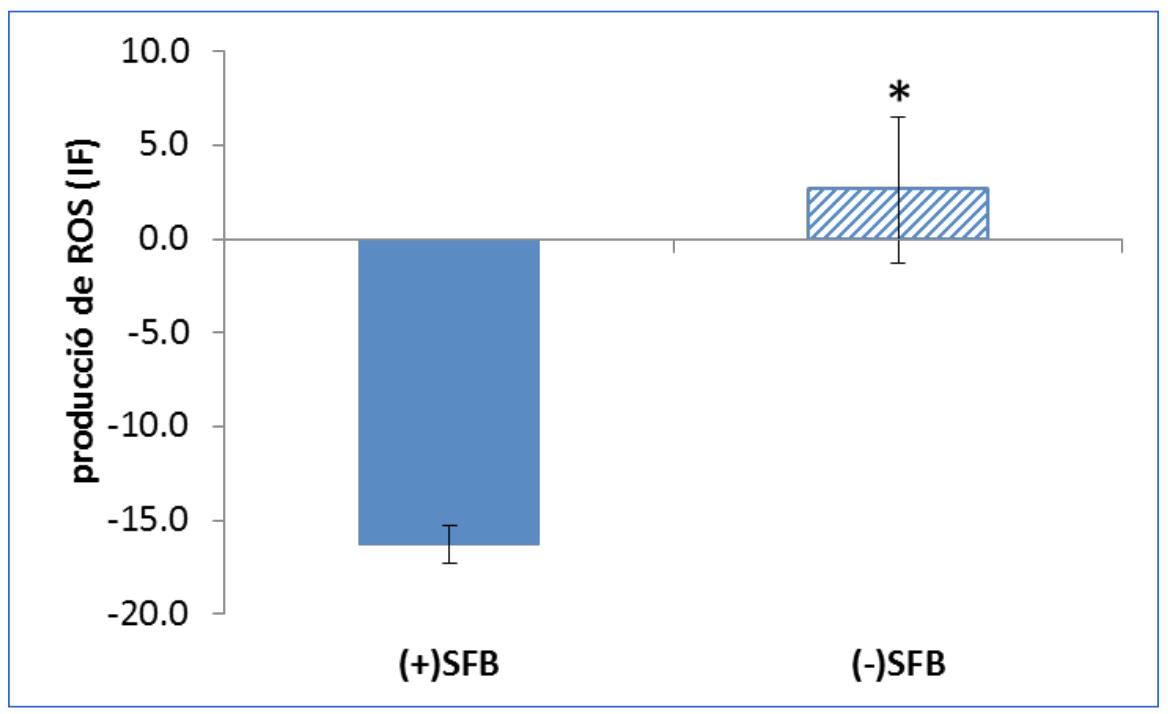

Figura 5. Producció de ROS en cèl-lules Caco-2 mantingudes en presència o en absència de SFB. Els resultats s'expressen com a mitjana \pm SE de $n=6$ cultius. L'asterisc denota diferències estadísticament significatives $(\mathrm{P}<0,05)$. IF: intensitat de fluorescència.

\subsection{Efectes de la complementació de diferents fonts de seleni sobre diferents selenoproteïnes}

Un cop establert que una deficiència de seleni comporta modificacions en les variables estudiades, l'objectiu següent és determinar els efectes que tenen diferents fonts de seleni sobre algunes d'aquestes. Aquests resultats es presentaran al IV Workshop Anual de l'INSA-UB (Campo-Sabariz et al., 2018).

En primer lloc, s'ha de determinar si l'interval de concentracions utilitzades $(0,1-625 \mu \mathrm{M})$ pot afectar la viabilitat celllular. Els resultats indiquen que la font orgànica no produeix citotoxicitat, mentre que la font inorgànica compromet la viabilitat de les cèlllules a concentracions per sobre de $5 \mu \mathrm{M}$ (figura 6). Aquests resultats confirmen la major toxicitat de les fonts inorgàniques respecte de les orgàniques, ja descrita (Suchý et al., 2014). 


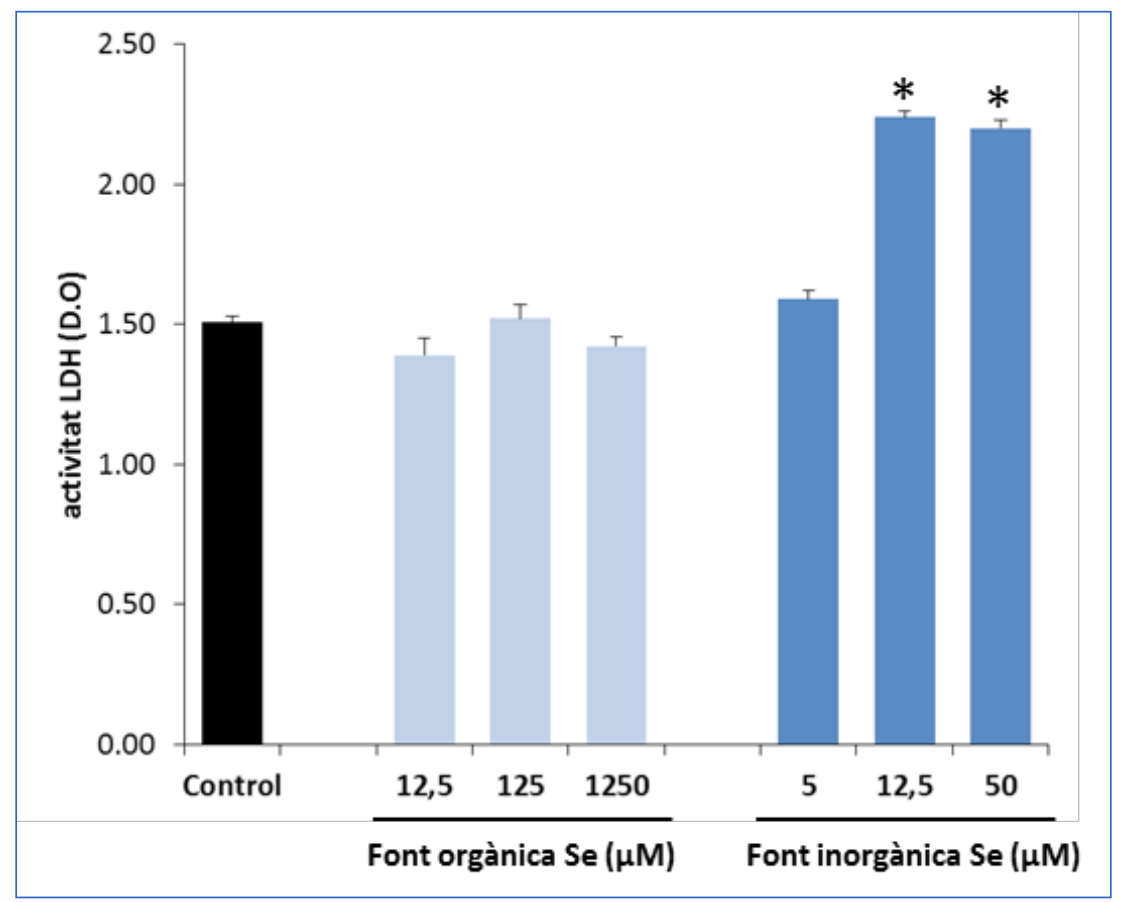

Figura 6. Activitat LDH en cèlllules Caco-2 mantingudes en presència de SFB i complementades amb 12,5 $\mu \mathrm{M}, 125 \mu \mathrm{M}$ i $1250 \mu \mathrm{M}$ d'una font orgànica $(n=6-11)$ o amb 5 $\mu \mathrm{M}, 12,5 \mu \mathrm{M}$ i $50 \mu \mathrm{M}$ d'una font inorgànica $(n=4-6)$. Els resultats s'expressen com a mitjana \pm SE de $n$ cultius. L'asterisc denota diferències estadísticament significatives respecte a la condició de control $(\mathrm{P}<0,05)$.

Tenint en compte aquests resultats, la complementació amb les diferents fonts de seleni en el model proposat s'ha dut a terme a diferents concentracions depenent de la forma química i de la variable estudiada:

- L'activitat de la GSH-Px i l'expressió proteica de la SEPP1 s'han determinat en cèlllules complementades amb la font orgànica a concentracions de 0,1-5-12,5-125-625 $\mu \mathrm{M}$ i amb la font inorgànica a concentracions de 0,1 i $5 \mu \mathrm{M}$.

- L'expressió gènica de la GSH-Px2 s'ha determinat en cèllules complementades amb la font orgànica a concentracions de 12,5 i $625 \mu \mathrm{M}$ i amb la font inorgànica a una concentració de $5 \mu \mathrm{M}$.

L'activitat de la GSH-Px es veu incrementada en presència de les diferents fonts de seleni; en el cas de la font orgànica, a partir de $12,5 \mu \mathrm{M}$ i en el cas de la font inorgànica, a $5 \mu \mathrm{M}$ (figura 7). Altres estudis en cèlllules Caco- 2 ja havien determinat que en presència de seleni aquesta activitat es veia modificada a l'alça de manera similar tant per una font orgànica com per una d'inorgànica (Wang i $\mathrm{Fu}, 2012$ ). En estudis fets en pollastres també s'ha demostrat que l'activitat de l'enzim GSH-Px s'incrementa linealment a mesura que s'incrementa la concentració de seleni en la dieta (Rao et al., 2013). En el treball present es demostra que la nova font orgànica investigada en aquest estudi també és capaç d'augmentar l'activitat d'aquest enzim de la mateixa manera que la font inorgànica. 


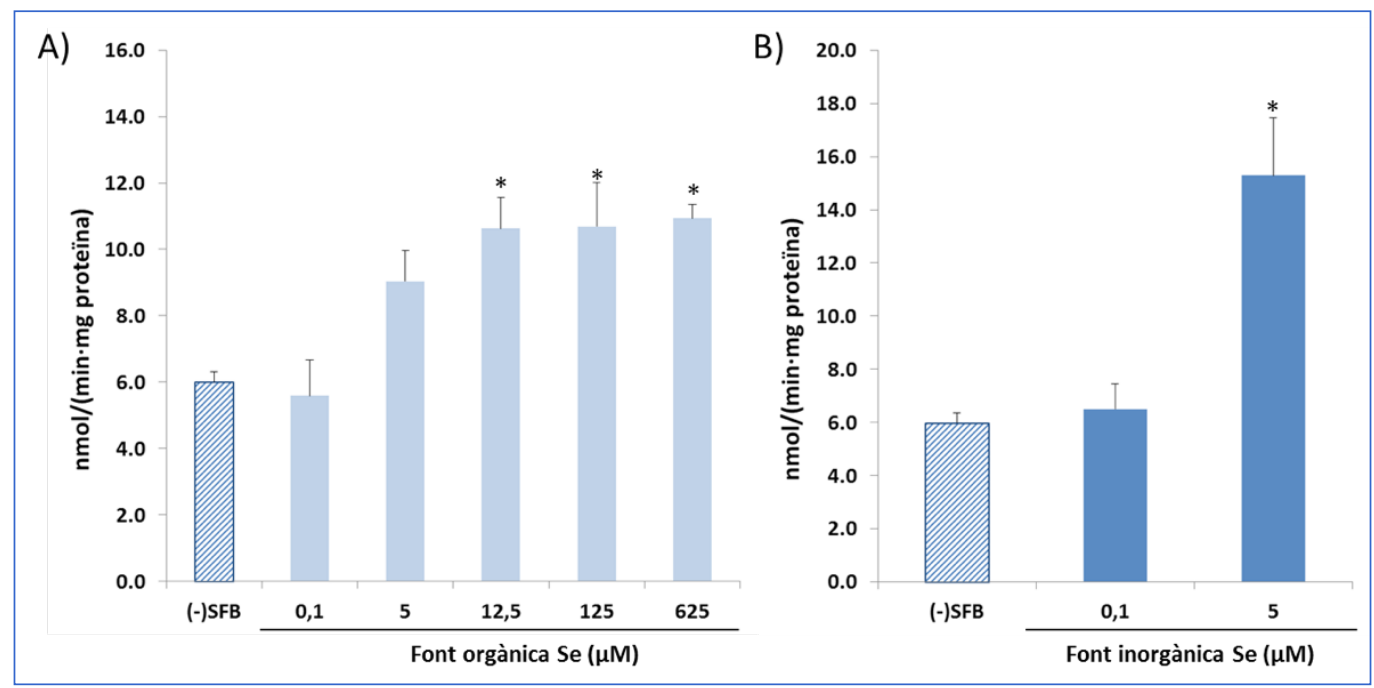

Figura 7. Activitat de la GSH-Px en cèl-lules Caco-2 mantingudes en absència de SFB i complementades amb (A) $0,1 \mu \mathrm{M}, 5 \mu \mathrm{M}, 12,5 \mu \mathrm{M}, 125 \mu \mathrm{M}$ i $625 \mu \mathrm{M}$ d'una font orgànica o (B) $0,1 \mu \mathrm{M}$ i $5 \mu \mathrm{M}$ d'una font inorgànica. Els resultats s'expressen com a mitjana \pm SE de $n=4-6$ cultius. L'asterisc denota diferències estadísticament significatives respecte als cultius no suplementats $(\mathrm{P}<0,05)$.

Els resultats referents a l'expressió gènica de la GSH-Px2 posen de manifest un increment d'aquesta només en la font orgànica i a una concentració de $625 \mu \mathrm{M}$ (figura 8). En aquest sentit, s'ha descrit que l'expressió gènica d'altres isoformes de la GSH-Px es veu augmentada només per les fonts orgàniques (Song et al., 2014), fet que dona suport als resultats obtinguts en el present treball. Cal remarcar que, tot i que a una concentració més baixa de les dues fonts de seleni ja hi ha un increment de l'activitat de la GSH-Px, només a concentracions elevades de la font orgànica hi ha variació de l'expressió gènica. De fet, des d'un punt de vista nutricional, s'ha comprovat que una font orgànica és superior a una d'inorgànica respecte al manteniment de l'enzim GSH-Px en períodes en els quals hi ha una deficiència de seleni (Lyons et al., 2007).

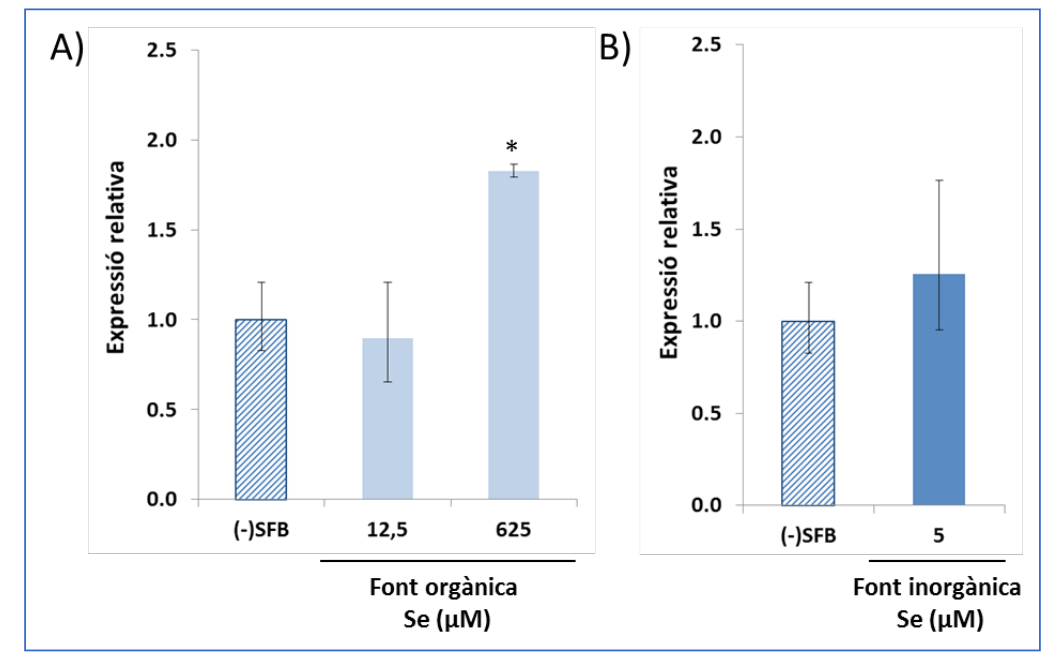

Figura 8. Expressió gènica relativa de la GSH-Px2 en cèlllules Caco-2 mantingudes en absència de SFB i complementades amb (A) 12,5 $\mu \mathrm{M}$ i $625 \mu \mathrm{M}$ de la font orgànica $\mathrm{o}(\mathrm{B}) 5 \mu \mathrm{M}$ de la font inorgànica. Els resultats s'expressen com a mitjana \pm SE de $n=4$ cultius. L'asterisc denota diferències estadísticament significatives respecte als cultius no suplementats $(\mathrm{P}<0,05)$. 
Pel que fa a l'expressió proteica de SEPP1, els resultats n'indiquen un increment en cèl·lules complementades només amb la concentració més alta de la font orgànica $(625 \mu \mathrm{M})$ i a una concentració de $5 \mu \mathrm{M}$ de la font inorgànica (figura 9). Tot i que no hi ha bibliografia que doni suport a aquests resultats, una possible explicació seria que l'expressió d'aquesta proteïna augmenta en les cèl·lules intestinals davant d'un excés de seleni amb l'objectiu de distribuir-lo a altres teixits o bé d'eliminar-lo. A baixes concentracions de les fonts orgàniques de seleni no es produeix un augment de l'expressió proteica respecte al grup no complementat perquè, com s'ha posat de manifest a la introducció, aquestes són més retingudes dins la cèl·lula en comparació amb les fonts inorgàniques. Per tal de completar aquests resultats i aprofundir en el paper d'aquesta selenoproteïna, seria interessant estudiar la seva expressió gènica en aquestes condicions.

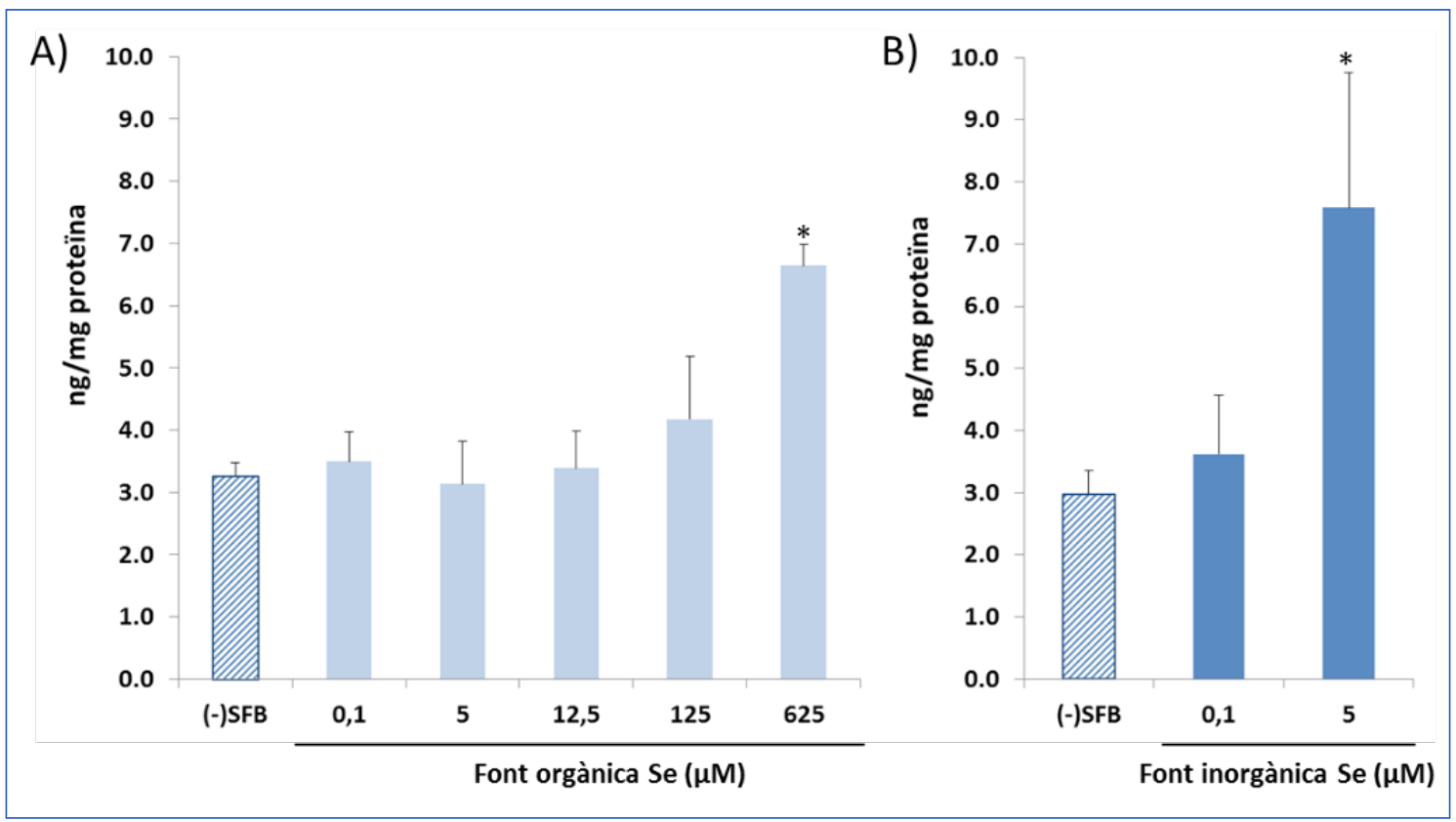

Figura 9. Expressió proteica de SEPP1 en cèlllules Caco-2 mantingudes en absència de SFB i complementades amb (A) $0,1 \mu \mathrm{M}, 5 \mu \mathrm{M}, 12,50 \mu \mathrm{M}, 125 \mu \mathrm{M}$ i $625 \mu \mathrm{M}$ de la font orgànica o (B) $0,1 \mu \mathrm{M}$ i $5 \mu \mathrm{M}$ de la font inorgànica. Els resultats s'expressen com a mitjana \pm SE de $n=4-6$ cultius. L'asterisc denota diferències estadísticament significatives respecte els cultius no suplementats $(\mathrm{P}<0,05)$.

\subsection{Efectes de la complementació amb diferents fonts de seleni sobre l'estrès oxidatiu generat per $\mathrm{H}_{2} \mathrm{O}_{2}$}

Amb l'objectiu de determinar el paper d'aquestes fonts davant l'estrès oxidatiu generat per $\mathrm{H}_{2} \mathrm{O}_{2}$, s'han determinat tant la producció de ROS (figura 10) com la peroxidació lipídica (figura 11) i l'oxidació proteica (figura 12). Els resultats indiquen que l'única font de seleni que protegeix davant l'estrès oxidatiu és la nova font orgànica en estudi a una concentració de $625 \mu \mathrm{M}$. 
Edusfarm 11-12 (2019-2020), 1-20

ISSN: $1886-6271$

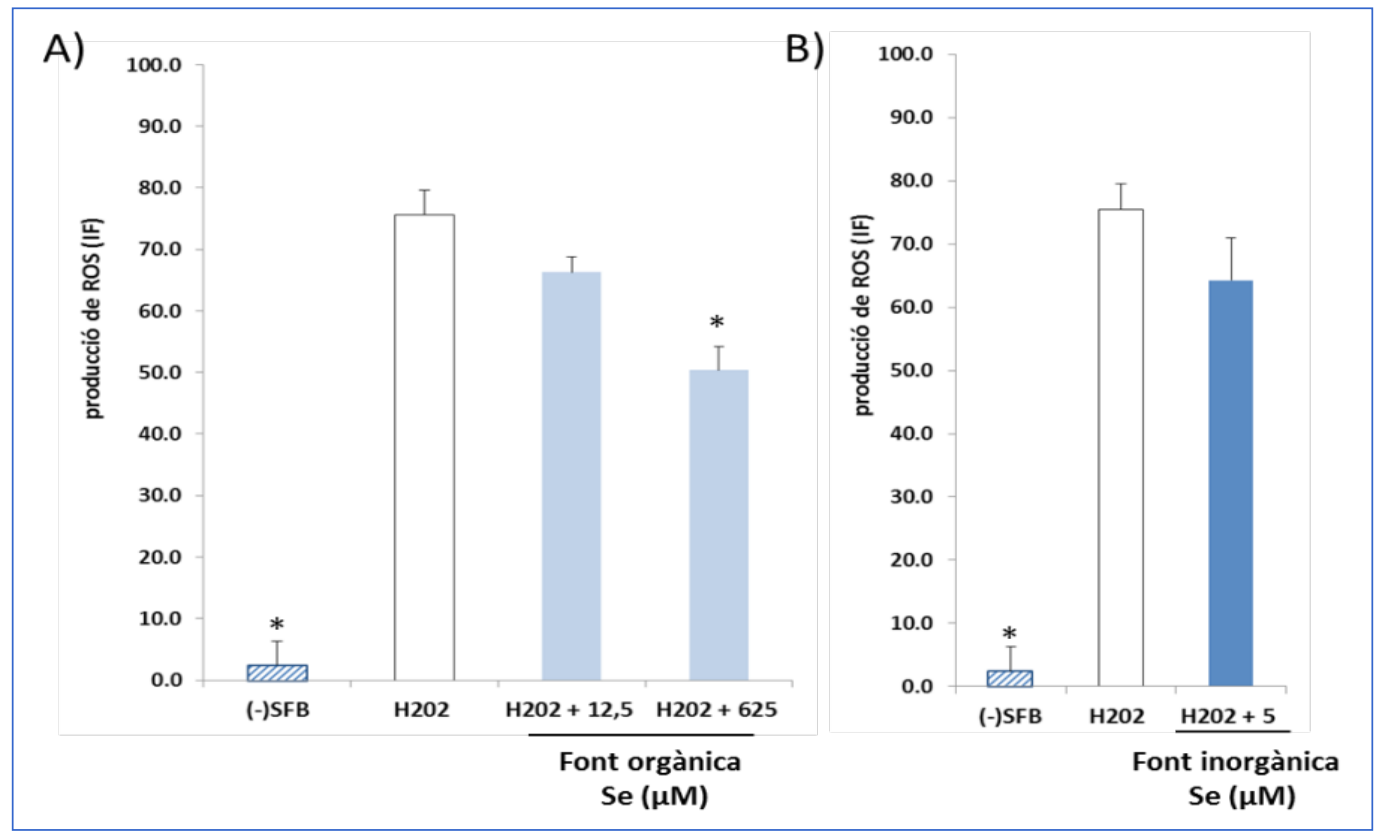

Figura 10. Producció de ROS en cèl-lules Caco-2 mantingudes en absència de SFB i estimulades amb $\mathrm{H}_{2} \mathrm{O}_{2}$ en absència d'una font de seleni o complementades amb (A) 12,5 $\mu \mathrm{M}$ i $625 \mu \mathrm{M}$ de la font orgànica o (B) 5 $\mu \mathrm{M}$ de la font inorgànica. Els resultats s'expressen com a mitjana \pm SE de $n=9$ cultius. L'asterisc denota diferències estadísticament significatives respecte als cultius estimulats amb $\mathrm{H}_{2} \mathrm{O}_{2}(\mathrm{P}<0,05)$. IF: intensitat de fluorescència.

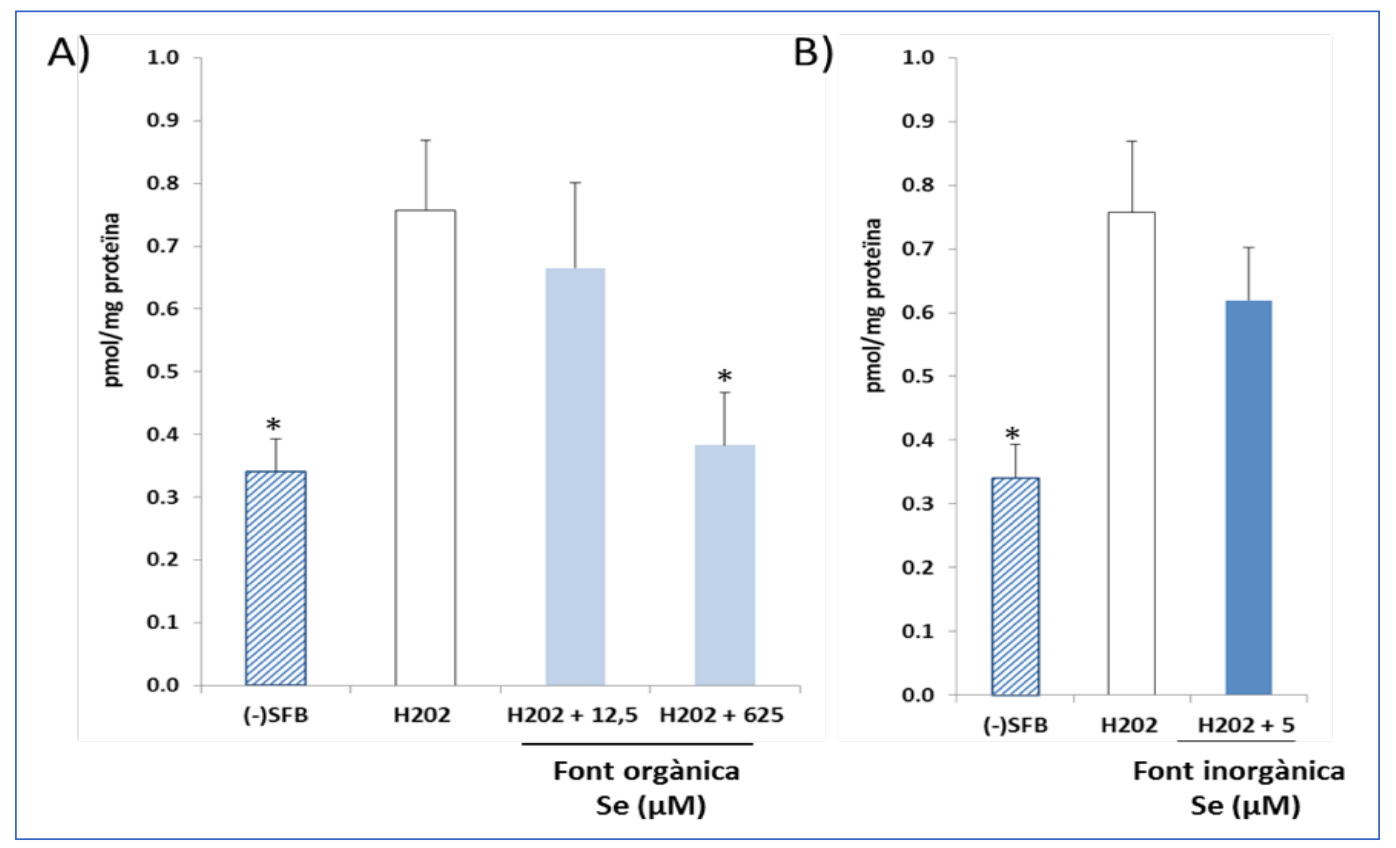

Figura 11. Peroxidació lipídica en cèllules Caco-2 mantingudes en absència de SFB i estimulades amb $\mathrm{H}_{2} \mathrm{O}_{2}$ en absència d'una font de seleni o complementades amb (A) 12,5 $\mu \mathrm{M}$ i $625 \mu \mathrm{M}$ de la font orgànica $\mathrm{o}(\mathrm{B}) 5 \mu \mathrm{M}$ de la font inorgànica. Els resultats s'expressen com a mitjana \pm SE de $n=4-6$ cultius. L'asterisc denota diferències estadísticament significatives respecte als cultius estimulats amb $\mathrm{H}_{2} \mathrm{O}_{2}(\mathrm{P}<0,05)$. 


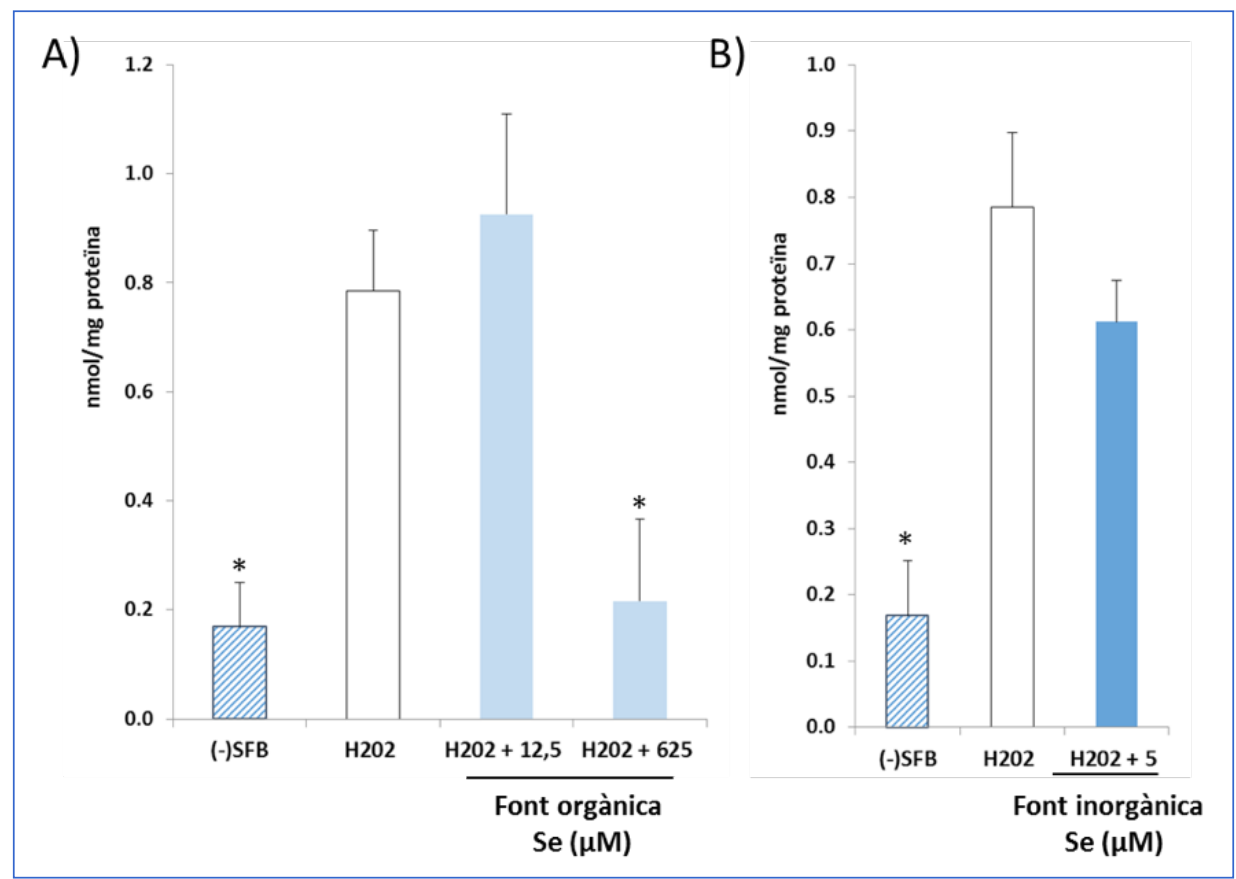

Figura 12. Oxidació proteica en cèlllules Caco-2 mantingudes en absència de SFB i estimulades amb $\mathrm{H}_{2} \mathrm{O}_{2}$ en absència d'una font de seleni o complementades amb (A) 12,5 $\mu \mathrm{M}$ i 625 $\mu \mathrm{M}$ de la font orgànica $\mathrm{o}$ (B) $5 \mu \mathrm{M}$ de la font inorgànica. Els resultats s'expressen com a mitjana \pm SE de $n=4-6$ cultius. L'asterisc denota diferències estadísticament significatives respecte als cultius estimulats amb l' $\mathrm{H}_{2} \mathrm{O}_{2}(\mathrm{P}<0,05)$.

Un dels enzims que té un paper més rellevant davant l'eliminació del $\mathrm{H}_{2} \mathrm{O}_{2}$ és la GSH-Px, de manera que els efectes de les diferents fonts de seleni sobre aquesta selenoproteïna poden justificar, en part, els resultats obtinguts. El fet que la complementació amb la font inorgànica no afecti l'expressió gènica de la GPH-Px2 podria explicar que aquesta font no exerceixi un efecte protector. S'ha descrit que, per tal que es pugui facilitar la síntesi proteica i, per tant, l'activitat enzimàtica d'aquesta selenoproteïna, és important que la font de seleni modifiqui l'expressió gènica (Song et al., 2014).

\section{Conclusions}

Les conclusions que es deriven d'aquest treball són les següents:

- Una deficiència de seleni comporta una modificació de l'expressió i/o l'activitat de diferents selenoproteïnes. Així, la determinació de la GSH-Px i la de la SEPP1 són uns bons marcadors per establir un model de deficiència de seleni en les cèllules intestinals Caco-2.

- La complementació dels cultius amb les dues fonts de seleni comporta un augment de l'activitat de la GSH-Px i de l'expressió proteica de la SEPP1. No obstant això, només les fonts orgàniques són capaces d'incrementar l'expressió gènica de la GSH-Px2.

- Davant d'un agent oxidant, l'única font de seleni que exerceix un efecte protector és la nova font orgànica en estudi, tant en la prevenció de la producció de ROS, en la de la peroxidació lipídica i de l'oxidació proteica.

Per acabar, cal remarcar que, tot i que calen més estudis que avaluïn l'efecte de la nova font orgànica de seleni sobre la salut intestinal dels pollastres d'engreix, els resultats obtinguts en aquest treball permeten afirmar que aquesta font de seleni és un bon candidat com a complement per a dietes de pollastres d'engreix. 


\section{Bibliografia}

BRADFORD, M.M. (1976) «A rapid and sensitive method for the quantitation of microgram quantities of protein utilizing the principle of protein-dye binding». Analytical Biochemistry (Reproduction Research Laboratories, Department of Biochemistry, University of Georgia), 72 (1-2), pp. 248-254.

Brandt-Kjelsen, A., Salbu, B., Haug, A., Szpunar, J. (2017) «Selenium Requirements and Metabolism in Poultry». Poultry Science, 1(8), pp. 149-170.

Campo-Sabariz, J., Moral-Anter, D., Brufau, M.T., Ferrer, R., Briens, M., Martín-Venegas, R. (2017) «Model of Se deprivation in Caco-2 cells and macrophages in culture». III Workshop anual INSA-UB. Santa Coloma de Gramanet, Institut de Recerca en Nutrició i Seguretat Alimentària de la Universitat de Barcelona.

Campo-Sabariz, J., Moral-Anter, D., Brufau, M.T., Briens, M., Ferrer, R., Martín-Venegas, R. (2018) «A novel organic selenium source is capable of up-regulating selenoprotein synthesis in intestinal Caco-2 cells». IV Workshop anual INSA-UB. Santa Coloma de Gramanet, Institut de Recerca en Nutrició i Seguretat Alimentària de la Universitat de Barcelona (comunicació acceptada).

Circu, M.L., Aw, T.Y. (2011) «Redox biology of the intestine». Free Radical Research, 45(11-12), pp. 12451266.

De Spirt, S., Eckers, A., Wehrend, C., Micoogullari, M., Sies, H., Stahl, W., Steinbrenner, H. (2016) «Interplay between the chalcone cardamonin and selenium in the biosynthesis of Nrf2-regulated antioxidant enzymes in intestinal Caco-2 cells». Free Radical Biology and Medicine, 91, pp. 164-171.

EDENS, F.W., GoWDY, K.M. (2004) «Selenium sources and selenoproteins in practical poultry production». En: Lyons, T.P., Jacques, K.A. (eds) Nutritional biotechnology in the feed and food industries. Proceedings of Alltech's 20th Annual Symposium: re-imagining the feed industry, Lexington, Kentucky, USA,

KHAN, M.T., Mahmud, A., Zahoor, I., Javed, K. (2016) «Organic and inorganic selenium in Aseel chicken diets: Effect on hatching traits». Poultry Science, 96(5), pp. 1466-1472.

Kipp, A., Banning, A., Van Schothorst, E.M., Méplan, C., Schomburg, L., Evelo, C., Coort, S., Gaj, S., Keijer, J., HESKETH, J., BRIGElius-FlohÉ, R. (2009) «Four selenoproteins, protein biosynthesis, and Wnt signalling are particularly sensitive to limited selenium intake in mouse colon». Molecular Nutrition \& Food Research, 53(12), pp. 1561-1572.

Kudva, A.K., Shay, A.E., Prabhu, K.S. (2015) «Selenium and inflammatory bowel disease». American Journal of Physiology-Gastrointestinal and Liver Physiology, 309(2), pp. G71-G77.

Lyons, M.P., PAPAZYAN, T.T., SuRAI, P.F. (2007) «Selenium in Food Chain and Animal Nutrition: Lessons from Nature -Review-». Asian-Australasian Journal of Animal Sciences, 20(7), pp. 1135-1155.

Maciel-Dominguez, A., SwAN, D., Ford, D., Hesketh, J. (2013) «Selenium alters miRNA profile in an intestinal cell line: Evidence that miR-185 regulates expression of GPX2 and SEPSH2». Molecular Nutrition \& Food Research, 57(12), pp. 2195-2205.

Martín-Venegas, R., Roig-PÉrez, S., Ferrer, R., Moreno, J.J. (2006) «Arachidonic acid cascade and epithelial barrier function during Caco-2 cell differentiation». Journal of Lipid Research, 47(7), pp. 14161423.

National Research Council (1994) Nutrient Requirements of Poultry. Washington, D.C.: National Academies Press.

Rao, S.V.R., Prakash, B., Raju, M.V.L.N., Panda, A.K., Poonam, S., Murthy, O.K. (2013) «Effect of supplementing organic selenium on performance, carcass traits, oxidative parameters and immune responses in commercial broiler chickens». Asian-Australasian Journal of Animal Sciences, 26(2), pp. 247-252.

Ravindran, V., Son, J.H. (2011) «Feed enzyme technology: present status and future developments». Recent Patents on Food, Nutrition \& Agriculture, 3(2), pp. 102-109.

Rayman, M.P., Infante, H.G., SARGent, M. (2008) «Food-chain selenium and human health: spotlight on speciation». British Journal of Nutrition, 100(2), pp. 238-253.

SCHRAUZER, G.N. (2000) «Selenomethionine: a review of its nutritional significance, metabolism and toxicity». The Journal of Nutrition, 130(7), pp. 1653-1656. 
SCHRAUZER, G.N. (2003) «The nutritional significance, metabolism and toxicology of selenomethionine». Advances in Food and Nutrition Research, 47(1), pp. 73-112.

Schrauzer, G.N., Surai, P.F. (2009) «Selenium in human and animal nutrition: Resolved and unresolved issues. A partly historical treatise in commemoration of the fiftieth anniversary of the discovery of the biological essentiality of selenium, dedicated to the memory of Klaus Schwarz (1914-1978) on the occasion of the thirtieth anniversary of his death». Critical Reviews in Biotechnology, 29(1), pp. 2-9.

Seo, Y.R., SweEney, C., Smith, M.L. (2002) «Selenomethionine induction of DNA repair response in human fibroblasts». Oncogene, 21(23), pp. 3663-3669.

Song, E., Su, C., Fu, J., Xia, X., Yang, S., Xiao, C., Lu, B., Chen, H., Sun, Z., Wu, S., Song, Y. (2014) «Selenium supplementation shows protective effects against patulin-induced brain damage in mice via increases in GSH-related enzyme activity and expression». Life Sciences, 109(1), pp. 37-43.

Speckmann, B., Bidmon, H.J., Borchardt, A., Sies, H., Steinbrenner, H. (2014) «Intestinal selenoprotein P in epithelial cells and in plasma cells». Archives of Biochemistry and Biophysics, 541(1), pp. 30-36.

SpeckmanN, B., Steinbrenner, H. (2014) «Selenium and Selenoproteins in Inflammatory Bowel Diseases and Experimental Colitis». Inflammatory Bowel Diseases, 20(6), pp. 1110-1119.

SuchÝ, P., Straková E., Herzig I. (2014) «Selenium in poultry nutrition: a review». Czech Journal of Animal Science, 59(11), pp. 495-503.

Surai, K.P., SuraI, P.F., SPEAKE, B.K., SPARKS, N.H.C. (2003) «Antioxidant-prooxidant balance in the intestine: Food for thought. 1. Prooxidants». Nutritional Genomics \& Functional Foods, 1(1), pp. 51-70.

Surai, K.P., Surai, P.F., SpeAKE, B.K., SPARKS, N.H.C. (2004) «Antioxidant-prooxidant balance in the intestine: Food for thought. 2. Antioxidants». Current Topics in Nutraceutical Research, 2(1), pp. 27-46.

SURAI, P.F. (2002) «Selenium in poultry nutrition 1. Antioxidant properties, deficiency and toxicity». World's Poultry Science Journal, 58(3), pp. 333-347.

SuRAI, P.F. (2006) Selenium in nutrition and health. Nottingham: Nottingham University Press.

SuRAI, P.F. (2016) «Antioxidant Systems in Poultry Biology: Superoxide Dismutase». Journal of Animal Research and Nutrition, 1(1:8), pp. 1-36.

WANG, Y., FU, L. (2012) «Forms of Selenium Affect its Transport, Uptake and Glutathione Peroxidase Activity in the Caco-2 Cell Model». Biological Trace Element Research, 149(1), pp. 110-116.

Yao, H., Zhao, W., Zhao, X., Fan, R., Khoso, P.A., Zhang, Z., LiU, W., Xu, S. (2014) «Selenium Deficiency Mainly Influences the Gene Expressions of Antioxidative Selenoproteins in Chicken Muscles». Biological Trace Element Research, 161(3), pp. 318-327.

Zeng, H., Botnen, J.H., Johnson, L.K. (2008) «A Selenium-deficient Caco-2 Cell Model for Assessing Differential Incorporation of Chemical or Food Selenium into Glutathione Peroxidase». Biological Trace Element Research, 123(1-3), pp. 98-108.

Zhao, X., Yao, H., FAn, R., Zhang, Z., XU, S. (2014) «Selenium Deficiency Influences Nitric Oxide and Selenoproteins in Pancreas of Chickens». Biological Trace Element Research, 161(3), pp. 341-349. 